Znanstveni radovi

UDK 811.111'42:574

811.163.42'42:574

81'27:574

Izvorni znanstveni članak

Prihvaćeno za tisak: 11. svibnja 2020.

https://doi.org/10.22210/suvlin.2020.089.01

Ivana Bašić, Marina Grubišić, Snježana Veselica-Majhut

Filozofski fakultet Zagreb

ibasicmobile@gmail.com

\title{
Diskursno oblikovanje klimatskih promjena u anglofonim i hrvatskim izvorima informiranja ${ }^{1}$
}

\begin{abstract}
Rad predstavlja rezultate eksplorativnog istraživanja načina diskursnog konstruiranja čovjekove uloge u fenomenu klimatskih promjena. Oslanjajući se na široki model ekolingvistike i kritičke analize diskursa u radu je provedena komparativna kvalitativna analiza korpusa tekstova o klimatskim promjenama objavljenih u hrvatskim i anglofonima online medijima u određenom, nasumce odabranom periodu. Cilj istraživanja jest utvrditi koje se priče (Stibbe 2015) o tom važnom društvenom problemu konstruiraju u analiziranom korpusu hrvatskih i anglofonih medijskih tekstova i koja se opća mjesta, odnosno toposi (Wodak 2001) aktiviraju u interpretaciji tih priča, kao i kakve se strategije konstruiranja društvenih aktera (van Leeuwen 2003) koriste u oba korpusa. Komparativnom kvalitativnom analizom tekstova iz anglofonih $i$ hrvatskih medija stječe se uvid u razlike u fokusu izvješćivanja, prominentnosti određenih (pod)tema u pojedinim sredinama i retoričkim strategijama oblikovanja samoga diskursa.
\end{abstract}

\section{Uvod}

Imajući u vidu rastuću važnost problema klimatskih promjena i njegovu sve veću zastupljenost u znanstvenom, političkom i medijskom prostoru, ovim radom želimo otvoriti raspravu o diskursnim praksama i diskursnom konstruiranju klimatskih promjena, koja u hrvatskom jezikoslovlju gotovo da i nije zastupljena². S obzirom na neosporan utjecaj medija na široku populaciju u ovom smo eksplorativ-

1 Istraživanje je financirano u sklopu institucionalnog projekta Antropocen i tamna ekologija anglofonije, voditeljice izv. prof. dr. sc. Ive Polak, Filozofski fakultet Sveučilišta u Zagrebu, šifra 1054. Također se želimo zahvaliti na iscrpnim, konstruktivnim i poticajnim recenzentskim komentarima.

2 Samo promišljanje čovjekove uloge i utjecaja u okolišu i na okoliš općenito je rijetka tema hrvatskih istraživanja u društvenim i humanističkim znanostima. Tim više treba istaknuti radove Matka Meštrovića, jer njegovo slojevito promišljanje dovodi u suodnos čitav niz disciplina iz društvenih i humanističkih znanosti (Meštrović 1980, 2016). 
nom istraživanju analizirali korpus tekstova s temom klimatskih promjena objavljenih u online izdanjima anglofonih i hrvatskih dnevnih novina te internetskih portala u razdoblju od mjesec dana. Istraživački problem i metodologija istraživanja postavljeni su u teorijski okvir kritičke analize diskursa i ekolingvistike. Jezične obrasce karakteristične za diskurs o klimatskim promjenama analizirale smo kao sredstvo konstruiranja i etabliranja mentalnih i kulturnih modela koji odražavaju uvriježene konceptualizacije čovjekovih uloga koje se ostvaruju u interakciji čovjeka, prirode i tehnologije u razdoblju antropocena, pri čemu se čovjek istovremeno pojavljuje u ulozi 'krivca' i/ili ‘spasitelja' i/ili ‘žrtve' vlastitoga djelovanja. U skladu s odabranim teorijskim okvirom, ovaj rad ima namjeru ukazati i na društveni potencijal načina oblikovanja diskursa o problemu klimatskih promjena (eng. climate discourse, climate communication; hrv. diskurs o klimi/klimatskim promjenama, komunikacija o klimi/klimatskim promjenama), koji je u anglofonim medijima prepoznat kao moćno sredstvo građanskog aktivizma u pokušaju osvješćivanja javnosti o težini problema i neodgodivosti poduzimanja radikalnih mjera koje bi ublažile nepovoljne (i u konačnici razorne) učinke ljudske aktivnosti. ${ }^{3}$

\section{Teorijski okvir}

Kao što je najavljeno u uvodu, jezično istraživanje u ovome radu smješta se unutar širokog okvira ekolingvistike i kritičke analize diskursa. Promišljanje suodnosa jezika i okoliša nalazimo u radu Einara Haugena (Eliasson 2015), koji je široko prihvaćen kao svojevrstan začetak ideja o jezičnoj ekologiji i ekologiji jezika (eng. language ecology i ecology of language). Bitan Haugenov (1972) doprinos upravo je u njegovu sveobuhvatnom, višeslojnom i dinamičnom pogledu na suodnos jezika i okoliša, što ističe i Eliasson (2015) u svome kritičkom prikazu Haugenove knjige. Eliasson (2015) smatra da je Haugen vrlo opsežno zahvatio temu ekologije jezika, obuhvativši i društvene znanosti i biologiju i lingvistiku u pokušaju da pojmove i podjele iz društvenih znanosti i biologije iskoristi u proučavanju jezika, ali nije ponudio jasno artikuliran pristup iz kojeg je vidljivo što se istražuje i unutar kojih granica područja ili discipline ${ }^{4}$. Bez obzira na nejasnoće u pristupu, kao što je već spomenuto, Eliasson vrlo jasno ističe da je »najvažniji doprinos toga pionirskog rada ukazivanje na nužnost dinamičkog i holističkog sagledavanja ljudskog jezika.«(Eliasson 2015: 90; istaknule autorice, prijevod naš). Ekolingvistika je rela-

3 Urednici nekih anglofonih novinskih kuća eksplicitno definiraju svoje stavove i politiku u izvještavanju o problemima okoliša i zagovaraju zaoštravanje retorike o klimatskim promjenama kao vid izravnog građanskog aktivizma i upiranja prstom u društvene aktere koji moraju nešto poduzeti prije nego što bude prekasno. Primjerice, engleski Guardian počeo je redovno koristiti kolokaciju climate catastrophe umjesto uvriježenog (i po njihovom sudu nedovoljno retorički jakog) climate change. Osim navedenoga, u pojedinim člancima pojavljuju se izrazi climate disaster te čak i climate apocalypse.

4 Ovdje je također bitno istaknuti i da se Haugen u svojoj upotrebi termina jezična ekologija koleba između jezične ekologije kao metafore o jednom specifičnom, sveobuhvatnom pogledu na jezik i jezične ekologije kao konkretnog područja istraživanja. 
tivno recentno područje lingvističkih istraživanja koje jezičnu produkciju smješta u još širi kontekst od društvenog, dakle u, najšire rečeno, sam ekosustav u kojem čovjek živi, djeluje i su-djeluje i tu okolinu upravo jezikom opisuje i gradi svoj odnos prema njoj. Kako definira Stibbe (2015: 6), uloga ekolingvistike je »analizirati tekstove kako bi se razotkrile 'priče' koje leže u njihovoj osnovi te promisliti na koje nas načine te priče potiču da djelujemo. Ako nas potiču na poštovanje i brigu za ekosustav koji podržava život, tada ih treba promovirati, a ako potiču ekološko uništenje, treba im se oduprijeti." (prijevod naš). Pritom priče i priče-prema-kojima-živimo ${ }^{5}$ Stibbe definira na sljedeći način:

'Priče su kognitivne strukture u umovima pojedinaca koje utječu na njihovu percepciju svijeta. Priče-prema-kojima-živimo su pričebrojnih pojedinaca unutar neke kulture.' (Stibbe, 2015: 6, prijevod naš)

Stibbe (2015) pojašnjava se da su kognitivne strukture mentalni modeli koji postoje u umu pojedinca i kolektivnoj svijesti zajednice (kulture), te kao takvi imaju snažan utjecaj na odnos pojedinaca i zajednice prema određenom problemu. Do tih priča, odnosno mentalnih modela, dopiremo između ostaloga i jezičnom analizom načina na koji se u određenim jezičnim zajednicama govori o određenom problemu. Takvo je viđenje posve u skladu s teorijskim postavkama kritičke analize diskursa, kojoj je cilj razotkrivanje uloge jezika u promicanju određenih ideologija (vidi Wodak i Meyer 2001). Pritom neki istaknuti teoretičari naglašavaju važnost proučavanja kolektivnih mentalnih modela, odnosno načina društvenog promišljanja i razumijevanja (eng. social cognition, Van Dijk 2009: 19) određenog problema jer način promišljanja o nečemu vodi prema načinu društvenog djelovanja (Jäger 2001: 37). Fairclough i Wodak (1997: 258) definiraju jezik kao oblik društvene prakse, a diskurs kao složenu mrežu sinkronijski i dijakronijski međusobno povezanih jezičnih činova koji se pojavljuju unutar određenih društvenih područja djelovanja kao tematski povezani »tekstovi« (Wodak 2001: 66) ili »fragmenti diskursa « (Jäger 2001:45) koji zajedno tvore jedan prepoznatljiv »diskursni pravac« (eng. discourse strand, Jäger 2001: 51). Na taj način prevladavajući diskurs u određenom povijesnom trenutku postaje »nositelj« znanja, zbog čega ima veliku društvenu moć:

'Diskursi imaju moć jer prenose znanje iz kojeg se napaja kolektivna i individualna svijest. Znanje koje pritom nastaje uporište je za individualno i kolektivno djelovanje i formativno djelovanje koje oblikuje stvarnost.' (Jäger 2001:38, prijevod naš)

Priklanjajući se osnovnoj postavci kritičke analize diskursa, prema kojoj diskursom oblikujemo stvarnost, kao što i stvarnost istovremeno oblikuje diskurs, u

5 Stibbe ovdje parafrazira Lakoffa i Johnsona i njihovu poznatu frazu »metafore prema kojima živimo« (eng. metaphors we live by), iz istoimene knjige objavljene 1980. godine, na hrvatski prevedene pod naslovom Metafore koje život znače (Disput, 2015., prevela Anera Ryznar). 
ovom smo radu željele istražiti načine diskursnog konstruiranja čovjekove uloge u problemu klimatskih promjena te utvrditi koje se priče o tom važnom društvenom problemu konstruiraju u analiziranom korpusu tekstova i koja se opća mjesta (toposi) aktiviraju u interpretaciji tih priča. Jedan od vodećih mislilaca antropocena, Timothy Morton, iznosi premisu da je čovjek u antropocenu istodobno "detektiv i zločinac" (Morton, 2017: 26)6. Mi smo u ovome radu odabrale izraze 'krivac', 'dobročinitelj' i 'žrtva' kao nazive općih mjesta (toposa) kolektivne svijesti i samim time pogodne interpretacijske okvire za analizu čovjekove uloge u geološkom razdoblju koje je započelo prije dvjestotinjak godina, a u novije vrijeme zadobiva znanstveno ime antropocen.

Komparativnom analizom tekstova iz anglofonih i hrvatskih medija željele smo dobiti uvid u razlike u fokusu izvješćivanja, prominentnosti određenih (pod) tema u pojedinim sredinama i retoričkim strategijama oblikovanja samog diskursa. U prvom redu željele smo vidjeti postoje li u hrvatskim medijskim izvješćima slične tendencije kao u anglofonima, odnosno jeli u izvješćima o klimatskim promjenama vidljivo da se radi o temi od izrazite društvene važnosti.

\section{Ciljevi istraživanja, istraživačka pitanja i metodologija analize}

Općeniti cilj ovog eksplorativnog istraživanja bio je istražiti diskursnu praksu, odnosno način komuniciranja o klimatskim promjenama u analiziranim online izdanjima na engleskomei hrvatskome jeziku, pri čemu smo primarno željele utvrditi načine diskursnog konstruiranja čovjekove uloge u problemu klimatskih promjena i utjecaja na okoliš. S tim smo ciljem postavile sljedeća istraživačka pitanja:

1. Tko/što se u analiziranom korpusu tekstova prikazuje kao akter/relevantan čimbenik u diskursu o klimatskim promjenama i utjecaju ljudske aktivnosti na okoliš?

2. Tko/što se prikazuje kao 'krivac', tko kao 'dobročinitelj', a tko/što kao 'žrtva' klimatskih promjena?

Istraživanje smo operacionalizirale na način da smo provele kvalitativnu analizu dijelova teksta u kojima se eksplicitno i implicitno iščitava čovjekova uloga te smo nastojale dati pregled najprominentnijih i najrelevantnijih toposa koje smo pronašle $u$ analizi, kao i retoričkih načina aktiviranja tih toposa, s posebnim naglaskom na strategije pozitivnog i negativnog predstavljanja aktera. Wodak (2001: 74) objašnjava da se u teoriji argumentacije pojam toposa koristi u značenju eksplicitno izraženih ili implicitnih premisa, odnosno "pravila zaključivanja« na temelju kojih se povezuju argumenti i izvodi zaključak. U Drews et al. (1985: 265) pojam toposa dovodi se u vezu s »kolektivnim simbolima« i »kulturnim stereotipima« koji se kolektivno koriste i prenose unutar neke zajednice i koji služe kao zajednička mjesta koja članovi društva prepoznaju i pomoću kojih predočavaju sliku društvene 
stvarnosti. Upravo kroz te okvire u diskursu se društvena stvarnost prezentira i interpretira (Jäger 2001: 35). Zbog toga su toposi pogodno sredstvo za analizu argumentacijskih shema u tekstovima koji su povezani određenim tematskim sadržajem. Wodak (2001: 74) navodi 15 toposa, od kojih će za našu analizu biti relevantni sljedeći: 'opasnost i prijetnja', 'zloupotreba', 'odgovornost', 'brojevi', te 'definiranje i interpretacija naziva'7. U analizi tekstova u našem korpusu izdvajamo topose oko kojih se isprepliće medijska priča o klimatskim promjenama, prvenstveno one pomoću kojih interpretiramo uloge i djelovanje društvenih aktera koji su diskursno prominentni. Topose koje smo izdvojile označavamo jednostrukim navodnicima. To smo smatrale primjerenim rješenjem jer se na taj način i grafički ukazuje na okvir unutar kojega se interpretira smisao društvenog djelovanja prikazanih aktera.

\subsection{Opis korpusa}

Korpus se sastoji od članaka koji se bave temom klimatskih promjena i utjecaja ljudske aktivnosti na okoliš objavljenih u online izdanjima anglofonih i hrvatskih novina i portala 8 - New York Timesa, Guardiana i Huffington Posta te Jutarnjeg lista, Večernjeg lista i Tportala u razdoblju između 16. 10. i 16. 11. 2018. Prikupljeni su svi članci s navedenom temom, bez obzira na to u kojoj su rubrici mrežnog izdanja objavljeni. Odabrane novine i portali pripadaju visoko čitanim, široko dostupnim sredstvima informiranja ${ }^{9}$. Prvi korak u prikupljanju podataka za korpus bio je svakodnevno prikupljanje svih tematskih relevantnih članaka. Drugi korak bio je pretraživanje online izdanja u promatranom razdoblju pomoću ključnih riječi (eng. climate, climate change, global warming; hrv. klima, klimatske promjene, globalno zatopljenje).

Guardian (UK edition) u rubrici News (Vijesti) koja se pojavljuje na naslovnici ima podrubriku Environment (Okoliš), koja pak ima posebnu rubriku posvećenu klimatskim promjenama, Climate Change (Klimatske promjene). Članci su preuzeti iz spomenute rubrike.

New York Times na početnoj mrežnoj stranici ima poveznicu na zasebnu rubriku koja se bavi pitanjima okoliša i klimatskih promjena pod nazivom Climate and

Wodak navodi sljedećih 15 toposa: korist, prednost; korist, nedostatak; definiranje, interpretacija naziva; opasnost i prijetnja; humanost; pravda; odgovornost; opterećenje, teret; financije; stvarnost; brojevi; pravo i ispravnost; povijest; kultura; zloupotreba.

8 Izvješćivanje o domaćim i svjetskim vijestima ubrzano se prenosi na mrežna izdanja, odnosno građani se najčešće informiraju putem internetski dostupnih izvora. Ovo je primarni razlog zašto se u radu koriste isključivo online izvori. Iako imaju svoja mrežna izdanja, Jutarnji list i Večernji list i dalje prvenstveno pripadaju onome što se smatra tradicionalnim medijima, svakako zbog svoje povijesti i mjesta u kulturnoj memoriji i praksi. The Guardian i The New York Times također pripadaju tradicionalnim medijima - tzv. legacy media na engleskom jeziku. Iako tradicionalni mediji i dalje imaju snažan utjecaj, internet je otvorio nepregledno područje djelovanja za digitalne medijske izvore. Huffington Post je upravo jedan takav digital-born media brand (Painter i dr. 2017: 84), medij izvješćivanja koji je u potpunosti izrastao u digitalnom okruženju, i kao takav je brz, svjež, interaktivan, široko dostupan, zbog čega je izrastao u izrazito moćan medij. Što se hrvatskih digitalnih medija tiče, u ovom radu koriste se podaci s tportala, dok će buduća istraživanja donijeti i rezultate i usporedbe s drugim digitalnim medijima izvješćivanja.

9 Portali imaju otvoren pristup svim rubrikama. Večernji list jedini ima kategoriju premium za pretplatnike, s odabranim izdvojenim reportažama, intervjuima i autorskim kolumnama. 
Environment (Klima i okoliš), tako da je većina članaka prikupljena upravo iz te rubrike. Nerijetko su se članci iz te rubrike paralelno objavljivali i na početnoj mrežnoj stranici (koju prema kriteriju vidljivosti i relevantnosti možemo smatrati ekvivalentom naslovnice u papirnatom izdanju novina) ${ }^{10}$.

Jutarnji list nema zaseban dio koji se bavi promatranom temom. Većinu članaka s temom okoliša i klimatskih promjena pronašli smo u rubrici Euractiv, u kojoj se objavljuju prijevodi članaka europskih novinskih kuća i izvorni hrvatski članci koji se bave relevantnim političkim i ekonomskim pitanjima u zemljama članicama Europske unije. 11 U promatranom razdoblju samo dva članka koja su se bavila predmetnom temom objavljena su na početnoj (naslovnoj) mrežnoj stranici Jutarnjeg lista.

Večernji list u svome online izdanju nema posebnu rubriku posvećenu okolišu, tako da su članci u našem korpusu preuzeti iz rubrike Znanost, u kojoj se povremeno objavljuju članci na tu temu.

Što se promatranih portala tiče, Huffington Post je mrežno mjesto s vijestima, reportažama, intervjuima i ostalim podžanrovima u sredstvima informiranja. Huffington Post sadržava zasebnu rubriku Environment (Okoliš), koja se nalazi unutar šire kategorije News (Vijesti). U rubrici Environment nalazimo tekstove koji su primarno pisani za tu rubriku i sadrže oznaku rubrike, kao i tekstove koji su preuzeti iz drugih rubrika s istog portala. U ovom radu članci su preuzeti isključivo iz rubrike Environment, i to oni koji su objavljeni s oznakom te rubrike. Tportal nema zasebnu rubriku o okolišu te su analizirani tekstovi preuzeti iz rubrika Vijesti i Biznis.

U promatranom razdoblju u Jutarnjem listu objavljeno je 9, a u New York Timesu 17 tekstova na temu klimatskih promjena. Večernji list objavio je 4 teksta na tu temu, a Guardian 11 tekstova. Tportal je imao 10 tekstova, dok je Huffington Post imao 16 tekstova u rubrici Environment (s oznakom Environment).

\section{Analiza}

U ovome dijelu predstavit ćemo nalaze analize prikupljenih tekstova o klimatskim promjenama u dva potpoglavlja. U potpoglavlju 3.1 predstavit ćemo nalaze analize tekstova s anglofonog područja, a u potpoglavlju 3.2 nalaze analize hrvatskih tekstova.

10 Nije naodmet istaknuti da se naslovnice u online izdanjima novina osvježavaju nekoliko puta tijekom dana, a pogotovo ako je u tijeku neki izvanredni događaj. U ovom radu nismo pratile vidljivost ciljanih tekstova na naslovnim stranicama portala niti na naslovnim stranicama pojedinih rubrika.

11 Na poveznici »O nama« u rubrici Euractiv na mrežnim stranicama Jutarnjeg lista navodi se: »EURACTIV je neovisna paneuropska medijska mreža specijalizirana za tematiku EU politike«, koja "pruža besplatne lokalizirane vijesti EU tematike na 13 jezika«. Nadalje se navodi da EURACTIV mreža portala surađuje s vodećim medijskim kućama u zemljama članicama EU-a (u Hrvatskoj s Hanza medijom), čija izdanja i novinari doprinose širini i kvaliteti vijesti koje se objavljuju na portalu. Općenito, cilj je portala izvješćivati o ključnim procesima na razini EU-a koji utječu na europske građane i na čitavu političku i ekonomsku klimu u Europi. 


\subsection{Analiza tekstova iz anglofonih medija}

U svim analiziranim anglofonim izvorima nalazimo na reference na ljude u najopćenitijem smislu (people ili humans), koji su konstruirani kao oni koji su odgovorni za nastale klimatske promjene, ali i kao oni koji mogu dovesti do pozitivnih pomaka (dakle, istodobno i kao 'krivci' i kao 'dobročinitelji'). Sve navedene skupine aktera ili individualne aktere možemo opisati i pojmom društvenih aktera, uvriježenim i u kritičkoj analizi diskursa (van Leeuwen 2003). Društvene aktere promatramo i analiziramo i kao pojedince (individualni društveni akteri) i kao skupine (kolektivni društveni akteri). Kao individualni društveni akteri u promatranim tekstovima najčešće se ističu političke figure - predsjednici, premijeri, ministri ili drugi predstavnici vlasti. Isticanje individualnih aktera potaknuto je snagom njihovog specifičnog društvenog statusa i opsegom djelovanja. Kolektivne društvene aktere upravo se takvima prikazuje kako bi se ukazalo na složnost ili istaknuo konsenzus koji drži tu društvenu skupinu na okupu. Van Leeuwen (2003) ukazuje na različite strategije kojima se u tekstovima prikazuje društvene aktere, ovisno o fokusu na individualno ili kolektivno i njihovom odnosu s drugim individualnim i kolektivnim akterima. S obzirom na naše primjere, i anglofone i hrvatske, izdvojile bismo diskursne strategije individualizacije i kolektivizacije te imenovanja i kategorizacije (van Leeuwen 2003) kao strategije kojima se opisuju i identificiraju relevantni društveni akteri.

Diskursnim strategijama individualizacije i imenovanja u analiziranim člancima izdvojeni su različiti dužnosnici, primjerice američki predsjednik Donald Trump i republikanski zakonodavci, bivši ministar vanjskih poslova John Kerry; brazilski predsjednik Jair Bolsonaro i brazilski ministar vanjskih poslova Ernesto Araújo.

U analiziranim tekstovima u New York Timesu i Guardianu pojedinac koji je diskursno eksplicitno pozicioniran kao 'krivac' u prvom je redu američki predsjednik Donald Trump. U diskursnom konstruiranju Trumpove krivnje u analiziranim tekstovima aktivira se topos 'zlouporabe' političkog utjecaja, koja se očituje kao Trumpovo svjesno negiranje problema klimatskih promjena, čime američki predsjednik izravno pridonosi pogoršanju situacije koju bi kao najviši izabrani politički dužnosnik trebao početi rješavati. Izvješća u kojima se prikazuju Trumpovi stavovi o problemu klimatskih promjena vrlo su često intonirana ironično, a uporabom kolokvijalnog registra i upuštanjem u zamišljeni dijalog s američkim predsjednikom postiže se učinak prikazivanja njegovih stavova kao nevjerodostojnih, što ilustriraju sljedeći primjeri:

(1) And then there was Mr. Trump, who gave an interview on CBS's nutes " on Sunday in which he again expressed his doubts about climate change, even suggesting that it may reverse itself. (Not going to happen, Mr. President.) (NYT19102018) 
[I onda kreće gospodin Trump, koji je u intervjuu u CBS-ovoj emisiji »60 minuta" ponovo izrazio sumnju u postojanje klimatskih promjena i čak sugerirao da bi promjene mogle krenuti u drugom smjeru. (Nema šanse, gospodine predsjedniče).]

Uz Trumpa kao individualiziranog društvenog aktera, kao kolektivni društveni akteri u negativnom sukontekstu prikazani i Trumpova vlada (eng. Trump administration) te skupina ljudi objedinjena pojmom poricatelji klimatskih promjena (eng. climate denialists), čiji se argumenti prikazuju kao toliko nevjerodostojni da se od njih ograđuju čak i oni u čijem je financijskom interesu negirati postojanje klimatskih promjena:

(2) President Trump has sometimes claimed that scientists are engaged in a worldwide hoax to fool the public, or that global warming was invented by China to disable American industry. The climate denialists' arguments have become so strained that even oil and coal companies have distanced themselves publicly, though some still help to finance the campaigns of politicians who espouse such views. (NYT19102018)

[Predsjednik Trump ponekad je izjavljivao da su znanstvenici upleteni u svjetsku prevaru kojom se obmanjuje javnost ili da je globalno zatopljenje izmislila Kina kako bi naštetila američkoj industriji. Argumenti onih koji osporavaju klimatske promjene postali su toliko nategnuti da su se od njih javno ogradile čak i kompanije koje trguju naftom i ugljenom, iako neke još uvijek financijski potpomažu kampanje političara koji iznose takve stavove.]

$\mathrm{U}$ istoj skupini negativno konstruiranih individualiziranih društvenih aktera zajedno s Trumpom pojavljuju se i brazilski predsjednik Jair Bolsonaro i brazilski ministar vanjskih poslova Ernesto Araújo (Guardian). U interpretacija njihove aktivnosti aktiviraju se toposi 'zlouporabe' političke moći te 'opasnosti' i 'prijetnje' od štetnih posljedica njihova djelovanja. Zanimljivo je primijetiti da se zajedno $s$ navedenim političarima u ulozi 'krivca' za zagađenje okoliša pojavljuje kolektivni društveni akter Kina, koju se apostrofira kao jednog od najvećih svjetskih zagađivača. Kao što je vidljivo iz primjera koji slijedi, za razliku od SAD-a i Brazila, gdje su 'krivci' individualizirani, u slučaju Kine 'zlouporaba', 'prijetnja' i 'odgovornost' ne povezuju se s aktivnošću pojedinih istaknutih političara nego se kao 'krivac' imenuje država, pri čemu se implicitno sugerira da u kineskoj politici niti ne postoji otpor takvome djelovanju:

(3) President Donald Trump is aggressively bolstering fossil fuel production while gutting greenhouse gas regulations. Brazil's incoming president, Jair Bolsonaro, is a right-wing demagogue who vowed to speed up deforestation in the Amazon and follow Trump's lead in withdrawing South 
America's biggest country from the Paris climate accords. China, the world's top emitter, is forging ahead with coal plants it promised to cancel. (HP7112018)

[Predsjednik Donald Trump agresivno gura proizvodnju fosilnih goriva, dok istovremeno koči donošenje novih propisa o emisijama stakleničkih plinova plinova. Novi brazilski predsjednik Jair Bolsonaro je desni demagog koji se zakleo da će ubrzati krčenje šuma u Amazoni i slijediti Trumpa u povlačenju Južne Amerike iz pariškog klimatskog dogovora. Kina, najveći zagađivač zraka na svijetu, i dalje gura planove o postrojenjima na ugljen, a obećala je da će ih ukinuti.]

Kadje riječ o američkim političarima, u anglofonim tekstovima često se citiraju izjave oporbenih političara koji eksplicitno upiru prstom u Trumpa kao moćnog i štetnog individualnog društvenog aktera, prokazuju ga kao 'krivca', prozivaju za 'zlouporabu' političke funkcije i ukazuju na 'prijetnju' i 'opasnost' koje proizlaze iz njegovog djelovanja. Jedan je od takvih primjera članak iz Guardiana (G16112018) pod naslovom »John Kerry: Europe must tackle climate change or face migration chaos [ [John Kerry: Europa se mora uhvatiti u koštac s klimatskim promjenama ili će se suočiti s migrantskim kaosom]. U članku se navodi snažno afektivno obojena izjava u kojoj predstavnik Demokrata i bivši američki ministar vanjskih poslova John Kerry individualizira Trumpovu 'krivnju' za štetno političko djelovanje u negiranju klimatskih promjena i ukazuje na 'odgovornost' koju Amerikanci (diskursno konstruirani upotrebom inkluzivnog »mi«) kolektivno snose u zaustavljanju takva štetnog djelovanja:

(4) We are heading for catastrophe unless we respond to some life-threatening challenges very rapidly. We have a climate-denying president that pulls us out of the the Paris climate change agreement at a time when literally every day matters. (G16112018)

[Na putu smo u katastrofu ako vrlo brzo ne reagiramo na neke izazove koji su prijetnja životu. Imamo predsjednika koji poriče klimatske promjene i koji se povukao iz Pariškog sporazuma o klimatskim promjenama u trenutku kad je doslovce svaki dan jako bitan.]

Za razliku od ranije spomenutih dužnosnika i vlada, koji su prikazani kao 'krivci', kao 'dobročinitelji' se diskursnom strategijom kolektivizacije pozicioniraju znanstvenici (scientists) ili se koriste izrazi koji se metonimijski odnose na znanstvenike i stručnjake koji su znanstvenim metodama došli do vjerodostojnih podataka o klimatskim promjenama. U izvješćima koja se pozivaju na znanstvene podatke aktivira se topos 'brojeva' znanstvenih istraživanja i dokaza u njima koji jasno ukazuju na 'prijetnju' i 'opasnost' i posredstvom kojih znanstvenici upozora- 
vaju na ozbiljnost situacije i političarima predlažu smjernice za djelovanje, što ilustriraju sljedeći primjeri:

(5) For the record: The percentage of scientists whose work supports the overwhelming evidence for climate change is itself overwhelming. (NYT19102018)

[Treba jasno reći: postotak znanstvenika čija su istraživanja rezultirala silnim brojem dokaza o postojanju klimatskih promjena sam je po sebi ogroman.]

(6) (...) there has been a lot of science in the news lately, especially the grim report from a United Nations science panel predicting enormous weather disasters by 2040, well ahead of previous estimates. (NYT19102018) [U vijestima se u posljednje vrijeme iznosilo puno znanstvenih podataka, posebice iz turobnog izvješća Znanstvenog panela Ujedinjenih naroda $u$ kojem se predviđaju vremenske katastrofe ogromnih razmjera do 2040 ., znatno prije nego što se ranije predviđalo.]

Osim znanstvenika, u Guardianu se kao individualni društveni akteri koji zahvaljujući svojem znanju nastoje pozitivno djelovati navode i predstavnici raznih institucija u čijem je djelokrugu briga o problemu klimatskih promjena. Tako Guardian, primjerice, citira Judith Enck, voditeljicu EPA-e (američke Agencije za zaštitu okoliša) za mandata Baracka Obame. U interpretaciji njezine izjave aktiviraju se toposi 'ispravnosti' i 'odgovornosti' za javno ukazivanje na 'opasnost' i 'prijetnju'.

(7) Enck said that EPA career staff are "frustrated « and "ashamed « about the new stance on climate change and urged her former colleagues to speak out. (G1112018).

[Enck je izjavila da su karijerni djelatnici EPA-e »frustrirani«i »posramljeni« zbog novog stava prema klimatskim promjenama i zahtijevala je od svojih bivših kolega da otvoreno progovore. ]

Uz navedene skupine, u Huffington Postu u ulozi 'dobročinitelja' pojavljuju se i kolektivni društveni akteri obuhvaćeni pojmom climate hawk(s) (doslovno, »klimatski jastrebovi«), metonimijsko-metaforička referenca na budno oko kojim te osobe nadziru državne i lokalne političke i gospodarske razine odlučivanja o problemima klime i klimatskih promjena. Uz kolokaciju climate hawks kao dodatna modifikacija koristi se pridjev progressive (referenca na njihove progresivne političke stavove), a u toj se skupini poimence izdvajaju neki pojedinci u Demokratskoj stranci 
(u analiziranom tekstu to su Alexandria Ocasio-Cortez, Ilhan Omar, Rashida Tlaib, Antonio Delgado) 12 .

U ulozi diskursno konstruiranih društvenih aktera u anglofonom se korpusu pojavljuju i različite institucije, od kojih su neke prikazane kao npr. EPA (Environmental Protection Agency; Agencija za zaštitu okoliša), UN, IPCC (Intergovernmental Panel on Climate Change; Međuvladin panel o klimatskim promjenama), te različite vlade i države (SAD, Saudijska Arabija, Kina, naftom bogate zemlje), što govori o tome da se klimatske promjene problematiziraju unutar sfere međunarodne politike.

Uz ranije istaknute ljudske aktere (uključujući i izraze koji se metonimijski odnose na ljudski rod), u člancima objavljenima u New York Timesu kao jedan od najistaknutijih aktera i glavni 'krivac' pojavljuju se i same klimatske promjene, jezično izražene kolokacijom climate change. Bez obzira na to jesu li rečenice $s$ takvim subjektom konstruirane kao aktivne ili pasivne, klimatske promjene prikazuju se kao personificirani, «živi« čimbenik koji je izravna 'opasnost' i 'prijetnja' okolišu i ekosustavu, a 'broj' vrsta i područja ugroženih klimatskim promjenama rapidno raste, što ilustriraju sljedeći primjeri:

(8) Climate change is ravaging California's underwater kelp forests. (NYT22102018)

[Klimatske promjene razaraju podvodne šume smeđih algi u Kaliforniji.]

(9) He wanted to see how the moose were faring, given that climate change has been delaying snow's arrival in New England's winters. (NYT18102018) [Želio je vidjeti u kakvom su stanju losovi, s obzirom na to da zbog klimatskih promjena snijeg i zima u Novoj Engleskoj kasnije stižu.]

(10) We're Covering Heritage Sites Threatened by Climate Change. The List Just Got Longer. (NYT18102018)

[Pišemo o mjestima s liste zaštićene svjetske baštine koja su u opasnosti zbog klimatskih promjena. Lista je upravo postala duža.]

(11) 47,000 Ticks on a Moose, and That's Just Average. Blame Climate Change. (NYT18102018)

[47 000 krpelja po losu, i to je samo prosječna brojka. Krive su klimatske promjene.]

12 Zbog stalnih glasnih poruka koje svakodnevno upućuju Ocasio-Cortez, Omar i Tlaib, ali i druge političarke i političari, na temu klimatskih promjena i šire, možemo pretpostaviti da će se kolokacija progressive climate hawks uvriježiti u medijima u opisu članova Demokratske stranke u SAD-u koji zagovaraju progresivne politike ili onih koji tu politiku zagovaraju i podržavaju. Dakako, ovu pretpostavku može se potvrditi isključivo daljnjim prikupljanjem i analizom podataka. 
Kao što je vidljivo iz gornjih primjera, u analiziranim člancima iz New York Timesa kao 'žrtve' klimatskih promjena prikazuju se pojedini ekosustavi, biljke i životinje, a ne izravno ljudi. U Guardianu se također neizravno upućuje na opasnost koja prijeti i ljudima od klimatskih promjena (climate change affects air, water, health). $\mathrm{U}$ primjeru koji slijedi, iz samoga naslova i podnaslova, koji su formulirani kao retorička pitanja, vidljivo je da se kao 'krivac' apostrofiraju same klimatske promjene:

(12) California fires: what is happening and is climate change to blame?, Is climate change playing a role? (G12112018)

[Požari u Kaliforniji: što se događa i jesu li klimatske promjene odgovorne za to? Imaju li klimatske promjene ulogu u tome?]

Čitateljima je ponuđen jasan potvrdan odgovor na postavljeno pitanje, u kojem se kao potpora koristi navod iz klimatološkog izvješća američke vlade:

(13) Climate change is increasing the vulnerability of many forests to ecosystem changes and tree mortality through fire, insect infestations, drought and disease outbreaks. (G12112018)

[Klimatske promjene pojačavaju osjetljivost brojnih šuma na promjene $u$ ekosustavima. Isto tako uvećavaju i smrtnost stabala uslijed požara, zaraza koje šire kukci, suše i pojave bolesti.]

$\mathrm{U}$ anglofonom korpusu tekstova izrazito je primjetno zaoštravanje retorike u diskursu o klimatskim promjenama, pri čemu se osim uvriježenog pojma climate change koriste i retorički snažniji pojmovi: climate breakdown, climate collapse, climate change catastrophe i climate crisis, što smo tumačili kao primjere diskursne strategije intenzifikacije (Wodak 2001) kojom se ukazuje na ozbiljnost problema i urgentnost situacije.

Uz same klimatske promjene, u New York Timesu se kao čimbenici koji izravno negativno utječu na okoliš prikazuju i pojedini zagađivači (primjerice, carbon dioxide emissions, greenhouse gas emissions, fossil fuel use), a u jednom se primjeru eksplicitno kao 'krivac' prikazuje i ljudski rod, odnosno ljudsko djelovanje:

(14) How do we know humans are responsible for the increase in carbon dioxide? (...) Hard evidence, including studies that use radioactivity to distinguish industrial emissions from natural emissions, shows that the extra gas is coming from human activity. (NYT13112018)

[Kako znamo da su ljudi odgovorni za porast u količini ugljikova dioksida? (...) Čvrsti dokazi, uključujući studije u kojima se koristi radioaktivnost da bi se razlikovale industrijske od prirodnih emisija, pokazuju da višak plina nastaje zahvaljujući ljudskoj aktivnosti.] 
U člancima objavljenima u Guardianu zamjećujemo čestu upotrebu jezičnih sredstava (superlativi pridjeva, intenzifikatori) kojima se ostvaruje diskursna strategija intenzifikacije.

(15) enormously destructive storms have already been bolstered by climate change (G14112018)

[silno razorne oluje su već ojačane klimatskim promjenama]

(16) the greatest environmental threathumankind has ever faced (G16112018) [najveća okolišna katastrofa s kojom se čovječanstvo ikad suočilo]

Upotrebu podcrtanih elemenata u gornjim primjerima unutar ukupnog konteksta rečenice, ali i šireg konteksta konkretnog klimatskog zbivanja tumačile smo kao diskursnu strategiju intenzifikacije jer se superlativi ovdje koriste upravo s namjerom pojačavanja dojma urgentnosti opisane situacije, dakle modificira se ilokucijska snaga iskaza korištenjem specifičnog jezičnog sredstva (Reisigl i Wodak 2009: 95). Primjerice, frazu poput enormously destructive storms u primjeru (15) možemo tumačiti dvojako - s jedne strane kao iskaz autorova stava, odnosno autorovu evaluaciju prikazane situacije, a s druge kao sredstvo kojim se potiču intenzivne emocije kod čitatelja. Naime, pridjevu destructive, koji već sam po sebi ima izrazito negativno značenje dodan je prilog enormously da bi se dodatno naglasio razmjer razornosti oluja koje se u nastavku rečenice eksplicitno označavaju kao posljedica klimatskih promjena. Dakle, oluje se prikazuju kao »nezamislivo razorne«, odnosno koristi se strategija intenzifikacije (Wodak 2001: 73) kako bi se dodatno naglasila 'opasnost' i 'prijetnja' od negativnih posljedica klimatskih promjena. U primjeru (16) referenca na klimatske promjene kao »okolišnu katastrofu « dodatno je ojačana kvalifikacijom da je posrijedi najveća katastrofa u povijesti. Uporabom superlativa, perfektivnog aspekta i priloga ever iskaz se intenzificira i jasno upućuje na ozbiljnost situacije.

Nadalje, jedna od često korištenih retoričkih strategija u stvaranju dojma ozbiljnosti prijetnje klimatskih promjena je projiciranje budućih katastrofičnih scenarija, pri čemu se upućivanjem na buduću 'prijetnju' i konstantan porast već postojeće 'opasnosti' intenzificira ilokucijska snaga iskaza, kao što se može vidjeti u sljedećim primjerima:

(17) This situation is set to worsen under future anticipated warming, however. (G14112018)

[Međutim, situacija će se sigurno pogoršati uslijed predviđenog budućeg zatopljenja.]

(18) [...] similar events in the future are on course to be cataclysmic. (G14112018)

[slični događaji u budućnosti najvjerojatnije će biti kataklizmički.] 
(19) [...] while preparing for more extreme weather to come. (G14112018) [dok se pripremaju za još ekstremnije vremenske uvjete u budućnosti.]

(20) [...] catastrophic 5C of warming, [...] (G16112018) [katastrofično zatopljenje od 5 stupnjeva Celzijusa,]

Osim što upozoravaju na katastrofične buduće scenarije, formulacije na koje nailazimo u Guardianu i Huffington Postu naglašavaju da klimatske promjene već sada dovode u pitanje sam ljudski opstanak:

(21) Like many scientists, Davis believes the world is currently in the midst of a sixth mass extinction ${ }^{13}$, also known as the anthropocene extinction or one caused by human activity. (HP16102018)

[Kao i mnogi drugi znanstvenici, Davis smatra da se svijet trenutno nalazi usred šestog masovnog izumiranja, poznatijeg kao izumiranje u razdoblju antropocena, odnosno izumiranje uzrokovano ljudskom aktivnošću.]

(22) it [climate change] affects air, water, health and whether large parts of the world will survive. (G01112018)

[one [klimatske promjene] negativno utječu na zrak, vodu, zdravlje i na to hoće li veliki dijelovi svijeta preživjeti.]

\subsection{Analiza tekstova iz hrvatskih medija}

U hrvatskom dijelu korpusa, u promatranome su razdoblju u Večernjem listu objavljena četiri teksta na temu klimatskih promjena ili njihovih manifestacija u svakodnevnome životu. Valja naglasiti kako su u tome razdoblju buknuli veliki požari u Kaliforniji, s velikim brojem ljudskih žrtava i značajnom materijalnom štetom. Budući da se radilo o događaju koji je bio medijski zanimljiv, Večernji list je vrlo iscrpno izvještavao o razvoju događaja u Kaliforniji, ali ni u jednom tekstu ih nije doveo u vezu s klimatskim promjenama. Za razliku od toga, britanski Guardian je izbijanje požara doveo u direktnu vezu s klimatskim promjenama (vidi primjere 12 i13).

Četiri teksta u Večernjem listu koja se eksplicitno bave temom klimatskih promjena žanrovski su različita: novinarsko izvješće, dva agencijska izvješća i intervju.

Zanimljivo je primijetiti da se $u$ analiziranome novinskom izvješću (VL30102018), sastavljenome povodom objave Izvješća o stanju planeta za 2018., koje je objavila Svjetska organizacija za zaštitu prirode (WWF), konstantno koristi

Šesto masovno izumiranje (sixth mass extinction), vidi Jackson (2008) i Wake i Vredenbrug (2008). Također vidi Waglerov osvrt (2013) koji sadrži pregled prethodnih pet doba izumiranja, predstavlja uzroke novog, šestog razdoblja te se obraća društvenim institucijama, pri čemu jasno ističe ulogu znanstvenog uvida i istraživanja kao temelja informiranja i poučavanja o čovjekovom utjecaju na okoliš i čovjekovoj odgovornosti: »Takva znanstveno utemeljena mjerila mogu potaknuti škole, regije, lokalnu i državnu upravu, nacionalna obrazovna tijela i mnoge druge dionike u obrazovnom sustavu da se u nastavne programe i sustav obrazovanja na učinkovit način ugrađuju teme i provode mjere koje potiču održivost.« (prijevod naš) 
inkluzivno »mi« u obraćanju čitateljima, čime se sugerira da smo »svi« kao pripadnici ljudskog roda u podjednakoj poziciji kada se radi o ljudskom utjecaju na stanje planeta:

(23) Prva smo generacija koja ima jasnu sliku o vrijednosti prirode i našem utjecaju na nju, možemo preokrenuti zabrinjavajuće trendove.

Navedena formulacija jasno ukazuje na to da članak ima apelativnu funkciju, tj. da ima funkciju djelovati na čitatelja kao onoga koji snosi dio 'odgovornosti' i koji svojim postupcima može nešto učiniti. U zaključnom dijelu članka ova retorička strategija postaje eksplicitna:

(24) Danas imamo znanje i sredstva za pronalaženje rješenja i nemamo izgovor za nedjelovanje. (VL30102018).

I u preostalim tekstovima u Večernjem listu koriste se slične strategije. Na primjer, upotreba inkluzivnog "mi« kojim se čitatelje uključuje kao izravno odgovorne, ali i kao one koji mogu pokrenuti potrebne promjene:

(25) Očekuje nas težak i dugotrajan rad. Od osobe do osobe, od zgrade do zgrade, od naselja do naselja, od postrojenja do postrojenja, od polja do polja. Moramo naći načine za smanjenje emisija [dioksida]. (VL14112018)

Čitatelje se uključuje i korištenjem retoričkih pitanja kojima ih se indirektno poziva da djeluju:

(26) Slušamo li ih [znanstvenike], mijenjamo li loše navike i ponašanja, postajemoli odgovorniji? (VL14112018)

Primjere inkluzivnog »mi« nalazimo i na Tportalu:

(27) Želimo li zauzdati klimatske promjene - kažu autori globalne mape - ne smijemo više dirati ni pedalj preostale netaknute divljine, čije su šume golemo skladište ugljika. (TP 10112018)

(28) A prašume smo dirali nesmiljeno, što dokazuju zastrašujuće brojke. (TP10112018).

Važno je također zamijetiti da se »ljudi« uglavnom diskursno konstruiraju kao čovječanstvo u cjelini, pri čemu su istodobno oni ti koji svojim ponašanjem dovode do klimatskih promjena i koji svojim budućim ponašanjem, imaju li svijest o važnosti klimatskih promjena, mogu utjecati na poboljšanje situacije. Ova je interpreta- 
cija, primjerice, eksplicitno vidljiva u primjeru: »Može li se onda reći da čovjek predstavlja najveću prijetnju za naš planet i za ljudsku civilizaciju, ali i da se u rukama čovjeka nalazi i spas? « (pitanje novinarke postavljeno klimatologu dr. Güttleru, VL 16.10.2019). U tom je segmentu vrlo važna uloga znanstvenika, koji su diskursno konstruirani kao zasebni kolektivni akter unutar amorfne mase »ljudi«, čija je uloga prosvjećivanje ostalog dijela čovječanstva. Konstruiranje znanstvene zajednice kao zasebne skupine, koja bi zahvaljujući spoznajama kojima raspolaže trebala biti predvodnik i davati upute za ispravno djelovanje, jasno se razaznaje u formulaciji pitanja koje novinarka postavlja znanstveniku u sljedećem primjeru:

(29) Budimo praktični, možete li savjetovati - što kao pojedinci, obični građani, možemo učiniti da na svojoj mikro-razini pomognemo spašavanju i izbjegavanju katastrofalnih posljedica? (VL16102018).

U promatranome razdoblju gotovo svi prilozi objavljeni na internetskom portalu Jutarnjeg lista bili su objavljeni u rubrici Euractiv, u podrubrikama Energija i gospodarstvo i Održivi razvoj. U čitavome razdoblju od mjesec dana samo dva članka s predmetnom temom objavljena su na početnoj (naslovnoj) stranici portala. Članci u hrvatskome izdanju Euractiva bili su uglavnom prevedene vijesti stranih medijskih kuća, većinom francuskih i njemačkih, pri čemu ispod članka stoji napomena "Članak je preuzet u cijelosti s portala Euractiv.com i preveden na hrvatski«. Samo jedan članak u Euractivu izvorno je izvješće hrvatskih novinara i govori o inicijativi hrvatske zastupnice u EU parlamentu Biljane Borzan, koja se zalaže za zabranu programiranog kvarenja uređaja zbog problema prekomjernog gomilanja otpada.

U člancima preuzetima od stranih partnera Euractiva kao glavni akteri i aktivni čimbenici u pitanjima okoliša i klimatskih promjena ističu se s jedne strane politička tijela EU-a i pojedinci koji obnašaju različite dužnosti u tim tijelima, a s druge različite industrije i njihovi predstavnici. U svim izvješćima te dvije strane predstavljene su kao čimbenici koji svojim aktivnostima i ciljanim politikama mogu najviše pridonijeti zaštiti okoliša i ublažiti negativne učinke ljudske aktivnosti na okoliš. U analiziranim člancima institucije Europske unije (i pojedinci koji obnašaju dužnosti u tim institucijama) gotovo se uvijek konstruiraju kao pozitivni akteri ('dobročinitelji'), čije su aktivnosti usmjerene na poduzimanje učinkovitih mjera kojima bi se suzbilo štetno djelovanje pojedinih oblika zagađenja okoliša, što ilustriraju sljedeći primjeri:

(30) Odbor za zaštitu okoliša Europskog parlamenta prošloga je tjedna odlučio proširiti listu zabranjenih plastičnih proizvoda. (JL15102018)

(31) Frédérique Ries (ALDE), belgijski zastupnik u Europskom parlamentu je u svome izvješću istaknuo potrebu da se do 2025. godine drastično reducira upotreba plastičnih ambalaža, osobito prilikom pakiranja hamburgera, sendviča, voća, povrća, deserta i sladoleda. (JL15102018) 
U analiziranim člancima nazire se tendencija da se u pozitivno intoniranim izvješćima koristi diskursna strategija imenovanja aktera, tj. akteri se jasno specificiraju na način da se navodi točno ime institucije koja je poduzela određene mjere u zaštiti okoliša, a u slučaju pojedinaca njihovo ime i prezime te funkcija koju obnašaju. Na taj se način jasno ukazuje kome pripada zasluga za poduzete aktivnosti. Za razliku od toga, u slučaju negativno kritički intoniranih izvješća na mjestu subjekta ('krivca') pojavljuju se obezličeni i uopćeni izrazi (primjerice, nacionalne vlade, europske vlade, naše vlade), što retorički stvara dojam kolektivne krivnje.

U iskazima kojima se izvješćuje o utjecaju pojedinih industrija na okoliš industrije se jezično oblikuju ili kao općeniti pojmovi (primjerice, duhanska industrija, industrija čelika, tvornice čelika, europski naftni sektor, europska naftna poduzeća, sektor nafte i plina) ili kao pojedine tvrtke, sa ili bez navođenja imena (RWE, Apple i Samsung, njemačka elektrana i rudnik ugljena). Pritom su u analiziranim člancima u podjednakoj mjeri zastupljena pozitivno i negativno intonirana izvješća, odnosno industrije se prikazuju i kao 'krivci' i kao 'dobročinitelji', primjerice:

(32) Njemačka elektrana i rudnik ugljena razotkriveni kao najgori onečišćivači zraka u Europi (JL31102018)

(33) U 24 kompanije, europske naftne tvrtke su zaslužne za 70 posto postojećih kapaciteta obnovljivih izvora energije i gotovo svih kapaciteta u razvoju - opisano je u izvješću CDP-a. (JL13102018)

Za razliku od europskih kompanija, koje se prikazuju kao svjesne problema okoliša kojima doprinose, američke i kineske kompanije prikazuju se kao neosviještene, što ukazuje na nedovoljnu angažiranost njihovih vlada u borbi za zaštitu okoliša, kao što je vidljivo u sljedećim primjerima:

(34) U prijelazu na obnovljive izvore energije, velike europske naftne kompanije prednjače nad američkim i kineskim. (JL13102018)

(35) Za razliku od njih (europskih tvrtki, op.a.), zbog manjih državnih pritisaka usmjerenih na promjenu, tvrtke sa sjedištem u SAD-u nisu prihvatile obnovljive izvore energije na isti način. (JL13102018)

Dok se same industrije diskursno konstruiraju istovremeno i kao 'krivac' i kao 'dobročinitelj', njihovi proizvodi i pojedine aktivnosti prikazuju se isključivo negativno, kao zagađivači okoliša (primjerice, zasebno se imenuju i kao zagađivači izdvajaju plastična vrećica, nepoželjni plastični artikli, plastične posude za dostavljanu hranu, boce za piće te opušci od cigareta, emisije ugljena, emisije iz dizelskih motora, emisije iz prometa, emisije čestica, emisije plinova od spaljivanja, spaljivanje fosilnih goriva, praksa spaljivanja, miješanje ugljika s koksom i rudom na visokoj temperaturi). 
U promatranom razdoblju samo dva članka s temom okoliša i klime pojavila su se na naslovnoj stranici portala Jutarnjeg lista, dakle na mjestu koje je najvidljivije i prvo se otvara pri pretraživanju portala. U jednom se slučaju radilo o izvješću o stanju okoliša u amazonskoj prašumi preuzetom od američke novinske agencije, a u drugome o izvješću o mladom hrvatskom znanstveniku koji radi u američkoj neprofitnoj udruzi koja razvija tehnologije za čišćenje oceana od plastike. Za razliku od članaka objavljenih u rubrici Euractiv, čiji je retorički stil uglavnom činjeničan, distanciran i objektivan, dva članka objavljena na početnoj stranici odlikuju se uporabom afektivnih izraza čija je funkcija privući pažnju čitatelja i djelovanjem na emocije upozoriti na ozbiljnost problema. Prvi članak nazvan je Zvono za uzbunu, a izvješćuje o dvojici američkih znanstvenika koji su se nakon četrdeset godina vratili u amazonsku prašumu koju su ranije istraživali i shvatili da je broj biljnih i životinjskih vrsta zabrinjavajuće manji te da su neke i posve nestale zbog promjena u okolišu izazvanih klimatskim promjenama. Članak obiluje pridjevima, kolokvijalizmima i drugim afektivnim izrazima kojima se ilokucijska snaga iskaza intenzificira i retorički se konstruira osjećaj nadolazeće katastrofe:

(36) znanstvenici su zaprepašteni; malo je reći da smo u šoku; težina najnovijih otkrića ogromna je i predstavlja znak za uzbunu. (JL16102018)

U članku se jasno pozicioniraju dvije strane - znanstvenici, koji se diskursno konstruiraju kao 'dobročinitelji' i 'prosvjetitelji' koji svojim znanjem i djelovanjem upozoravaju na 'opasnost' i čine što mogu da spriječe katastrofu, a s druge strane američka politika, kao 'krivac', jer bi trebala poduzeti adekvatne mjere, a oglušuje se, što predstavlja 'zlouporabu' političke dužnosti:

(37) Stanje je zabrinjavajuće. Situacija nije dobra, kaže Merrill (znanstvenik, op.a.) procjenjujući da je svijetu preostalo tek desetak godina da se trgne i pokuša nešto učiniti. Trebali bismo ubrzati. Početi koristiti ekološkije automobile i pogasiti nepotrebnu elektroniku. Nažalost, u Washingtonu nas trenutno nitko ne sluša. No, $s$ vremenom će morati početi slušati jer će $u$ opasnost doći zalihe hrane. (JL16102018)

Zanimljivo je primijetiti da se u primjeru 37 konstruiraju dvije suprotstavljene strane: "mi ( jednom u značenju ljudske vrste, a drugi put u značenju znanstvene zajednice) $i$ »oni« (u značenju političara). Istovremeno, imenica svijet također se koristi u značenju ljudske vrste, a ne planeta. To je vidljivo iz načina argumentiranja, odnosno iz toga što se svijet konstruira kao živo biće koje nema puno vremena da se »trgne«i »pokuša nešto učiniti«.

Drugi članak koji se pojavio na naslovnici online izdanja Jutarnjeg lista u promatranom razdoblju izvješće je o američkoj neprofitnoj udruzi koja je pokrenula projekt razvoja tehnologije za čišćenje svjetskih oceana od plastike. Iako sam tekst 
obiluje činjenicama (navodi se da u udruzi radi više od 80 inženjera, istraživača i znanstvenika, iznose se podaci o količini plastike koja se godišnje baci u oceane (aktiviranje toposa 'brojeva', usp. 3.1) te o posljedicama za životinjski svijet u oceanima) naslov teksta retorički je konstruiran senzacionalistički, tako da se diskursnom strategijom individualizacije u ulogu zaštitnika svjetskih oceana od plastike postavlja mladi Hrvat:

(38) Projekt života mladog Hrvata: krenuo u misiju spašavanja svjetskih oceana, (JL17102018)

U samome tekstu kao kolektivni društveni akteri koji su aktivni 'dobročinitelji' i zaštitnici okoliša prikazuju se inženjeri, istraživači i znanstvenici, kao zagađivač plastika, a kao žrtve morska stvorenja i ptice.

Zanimljivo je primijetiti da je i članak s Euractiva koji govori o aktivnostima hrvatske eurozastupnice Biljane Borzan drugačije retorički konstruiran od članaka koji su preuzeti od stranih medijskih kuća. Naime, i u tome članku naglasak je na afektivnosti, a diskursna strategija individualizacije koristi se kako bi se hrvatska zastupnica prikazala kao osoba koja se samostalno suprotstavlja velikoj i snažnoj nepovoljnoj sili, pri čemu se koristi i strategija intenzifikacije, tj. uporabom imperativa s uskličnikom, imenice apel te pridjeva hitan pojačava se dojam urgentnosti situacije i snažnog angažmana subjekta u rješavanju situacije:

(39) Nova inicijativa Biljane Borzan: 'Zabranite namjerno kvarenje uređaja!'; Biljana Borzan poslala je apel Europskoj komisiji za hitnu zabranu programiranog kvarenja na razini EU. (JL30102018).

\subsection{Rasprava i zaključci}

Usporedbom analiziranog korpusa tekstova na temu klimatskih promjena $u$ hrvatskim i anglofonim sredstvima informiranja uočavaju se sljedeće razlike:

1. Anglofoni izvori zastupljeni u korpusu imaju posebne rubrike posvećene temi okoliša i klimatskih promjena i redovno objavljuju priloge o tim temama. Osim u posebnim rubrikama, tekstovi s tom temom pojavljuju se i na početnoj mrežnoj stranici (naslovnici), čime se jača njihova vidljivost. U usporedbi s promatranim anglofonim izvorima, u hrvatskim izvorima tema okoliša i klimatskih promjena obrađuje se znatno rjeđe i ne postoje zasebne rubrike koje se bave isključivo tom temom.

2. U anglofonim izvješćima o klimatskim promjenama nerijetko se koriste afektivno obojen jezik, kolokvijalizmi, ironija, konstruirani dijalozi u obliku pitanja i odgovora te ostala retorička sredstva pomoću kojih se privlači pažnja čitatelja, održava njihov interes i uvjerava ih se u iznesene tvrdnje i stajališta. Za razliku od toga, izvješća u dijelu tekstova iz hrvatskog korpusa, posebice iz Jutarnjeg lista, variraju između faktografskih i distanciranih s jedne strane te naglašeno senzacionalističkih s druge, što bi moglo ukazivati na nepostojanje jasnih uredničkih politika o 
načinu izvještavanja o toj temi. Večernji list koristi različite žanrove, što, očekivano, ima za posljedicu širi repertoar retoričkih sredstava. Međutim, za razliku od anglofonih izvora, u tekstovima u Večernjem listu klimatske promjene ne dovode se na razinu političke teme i u izvješćivanje o temi ne uvode se razni politički akteri.

3. Leksička i frazeološka analiza tekstova iz korpusa pokazale su da diskursna praksa u izvješćivanju o klimatskim promjenama u anglofonim izvorima pokazuje znatno razrađenije skupove fraza i ustaljenih kombinacija riječi nego u hrvatskim. Primjetno je da se radi o temi o kojoj se puno piše i za opis koje je razvijen bogat repertoar jezičnih izraza, primjerice climate activist, climate science, climate scientists, climate science denial, climate science denialists, global climate movement, climate negotiation experts, climate advocates, $5 \mathrm{C}$ climate change, climate policies, climate commitments, government climate pledges, climate agreement, climate accord, climate mitigation, climate mitigation narratives, climate action, climate migrants, climate pollution, climate hawks. Pritom se repertoar izraza koji se koriste u diskursu o klimatskim promjenama često proširuje izrazima koji se u tome diskursu koriste u svrhu intenzifikacije iskaza, jačanja njegove ilokucijske snage, upućivanja na urgentnost situacije i afektivnog djelovanja na čitatelja. Za razliku od toga, u analiziranim se hrvatskim izvješćima primjećuju kolebanja i neusustavljenost čak i u uporabi osnovnih pojmova vezanih uz predmetnu temu (primjerice, uz pojam klimatske promjene zna se pojaviti i kolokacija klimatska promjena, štoje očit utjecaj engleskogjezika).

Zaključno, analiza korpusa dala je sljedeće odgovore na postavljena istraživačka pitanja:

U analiziranom korpusu tekstova kao akteri i relevantni čimbenici u diskursu o klimatskim promjenama pojavljuju se sljedeće skupine: političari, znanstvenici, aktivisti, industrije te sam ljudski rod. Osim ljudskih aktera (uključujući i izraze koji se metonimijski odnose na ljude), u brojnim tekstovima i sam pojam klimatskih promjena pozicionira se kao aktivan čimbenik koji utječe na ekosustav.

Od ljudskih subjekata, u analiziranom korpusu političari se pojavljuju i kao 'krivci' i kao 'dobročinitelji' koji mogu doprinijeti pozitivnoj promjeni. Europski političari te američki političari koji pripadaju Obaminoj administraciji te Demokratskoj stranci, obično se pojavljuju u pozitivno intoniranim izvješćima, dok se američki predsjednik Trump i brazilski predsjednik Bolsonaro pojavljuju isključivo u ulozi 'krivca'. Znanstvenici i aktivisti pojavljuju se u ulozi 'dobročinitelja' (u slučaju znanstvenika i 'prosvjetitelja'). Industrije se pojavljuju u dvostrukoj ulozi, i kao 'krivci' za zagađenje, ali i kao promicatelji pozitivnih promjena. Kao ‘žrtva' klimatskih promjena najčešće se prikazuje sam ekosustav (biljke i životinje, voda, priroda općenito) te posredno sam ljudski rod.

U konstruiranju priča o klimatskim promjenama u analiziranom korpusu aktivira se nekoliko toposa. U oba analizirana korpusa 'opasnost' i 'prijetnja' posljedica su ljudske aktivnosti i ljudi imaju 'odgovornost' poduzeti aktivne mjere da spriječe katastrofu. 'Opasnost' i 'prijetnja' proizlaze ne samo iz 'zloupotrebe' prirode i okoliša, nego i iz 'zloupotrebe' političke moći, što je posebno naglašeno u anglofonom 
korpusu, posebice u politički lijevo orijentiranima New York Timesu i Guardianu, u izravnom upućivanju na sadašnjeg američkog predsjednika Trumpa, koji poricanjem problema i/ili aktivnim odbijanjem da sudjeluje u pronalaženju rješenja nanosi ogromnu štetu. Za razliku od toga, u analiziranim hrvatskim medijima, $u$ prikazu političkog djelovanja europskih političara aktivira se topos 'odgovornosti', pri čemu se europski političari diskursno konstruiraju kao odgovorni pojedinci (i institucije) koje, iako ponekad ne dovoljno brzo, aktivno rade na rješavanju problema zaštite okoliša. U prikazu uloge znanstvene aktivnosti i znanstvenika u oba se analizirana korpusa često aktivira i topos 'brojeva', odnosno pomoću znanstvenih podataka upućuje se da broj vrsta i ekosustava pogođenih klimatskim promjenama konstantno raste, kao što raste i broj i učestalost elementarnih nepogoda koje su posljedica klimatskih promjena. Aktiviranjem toposa 'brojeva' intenzificira se dojam urgentnosti situacije te ukazuje na porast 'opasnosti' i 'prijetnje'. Konačno, u medijskoj priči o klimatskim promjenama aktivira se i topos 'definiranja i interpretacije naziva', prvenstveno posredstvom retoričkog preoblikovanja postojećih pojmova i konstruiranja novih, kojima se želi intenzificirati dojam urgentnosti, ukazati na potrebu aktivnog otpora normalizaciji štetne ljudske aktivnosti te potaknuti čitatelje na aktivno djelovanje u sprečavanju razornog utjecaja klimatskih promjena za koje je 'odgovorna' ljudska aktivnost.

Iako je naše istraživanje bilo eksplorativno i analiziran je razmjerno ograničen korpus (tekstovi objavljeni unutar jednog mjeseca), u analizi se jasno razabiru glavne tendencije u diskursnom oblikovanju klimatskih promjena. Ove tendencije upućuju nas na daljnja istraživačka pitanja koja bi trebalo postaviti u budućim opsežnijim istraživanjima diskursa o klimatskim promjenama. Jedno od područja istraživanja svakako je interdiskursnost tekstova o klimatskim promjenama, pri čemu bi bilo potrebno iz kuta kritičke analize diskursa istražiti kako se is kojim ciljem različiti diskursi (diskurs znanosti, diskurs politike, diskurs aktivističkih pokreta) ugrađuju u diskurs medijskih izvješća. Također, u današnje je vrijeme prijeko potrebno u lingvistička istraživanja uključiti i multimodalnu analizu diskursa (Kress i van Leeuwen 2006, Kress 2010), koja bi obuhvatila i vrlo bogat vizualni materijal koji prati verbalne poruke (vidi npr. Dahl 2017, Sedlaczek 2017).

\section{Reference:}

Drews, Axel, Gerhard, Ute i Link, Jürgen. (1985). Moderne Kollektivsymbolik. Eine diskurstheoretisch orientierte Einführung mit Auswahlbibliographie. Internationales Archiv fur Sozialgeschichte der deutsche Literatur (IASL). Tübingen: Forschungsreferate, 256-375

Eliasson, Stig (2015). The birth of language ecology: interdisciplinary influences in Einar Haugen's »The ecology of language«. Language Sciences 50: 78-92, https://doi.org/10.1016/j.langsci.2015.03.007

Haugen, Einar (1972). The Ecology of Language. Stanford University Press 
Dahl, Trine (2017). Verbal and visual framing activity in climate change discourse: a multimodal analysis of media representations of the IPCC's 5th Assessment Report

Fairclough, Norman i Ruth Wodak (1997). Critical discourse analysis. van Dijk, Teun (ur.) Discourse Studies: A Multidisciplinary Introduction. Volume 2. London: Sage, 258-284

Fløttum, Kjersti (ur.) (2017). The Role of Language in the Climate Change Debate. Abingdon: Routledge

Jackson, Jeremy B. C. (2008). Ecological extinction and evolution in the brave new ocean. Proceedings of the National Academy of Sciences of the United States of America 105 (Supplement 1): 11458-11465, https://doi.org/10.1073/pnas.0802812105

Jäger, Siegfried (2001). Discourse and knowledge: theoretical and methodological aspects of a critical discourse and dispositive analysis. Wodak, Ruth i Michael Meyer (ur.) Methods of Critical Discourse Analysis. London: Sage Publications, 32-62

Kress, Gunther (2010). Multimodality. A Social Semiotic Approach to Contemporary Communication. London: Routledge

Kress, Gunther i Theo van Leeuwen (2006). Reading Images: The Grammar of Visual Design: Routledge

Lechevrel, Nadège (2009). The intertwined histories of ecolinguistics and ecological approaches of language(s): Historical and theoretical aspects of a research paradigm. Symposium on Ecolinguistics: The Ecology of Science. University of Southern Denmark, Odense, Denmark. Dostupno na:

https://halshs.archives-ouvertes.fr/halshs-00413983/document (pristup 15. srpnja 2019.)

Meštrović, Matko (1980). Teorija dizajna i problemi okoline. Zagreb: Naprijed

Meštrović, Matko (2016). Antropocen - kakav kraj kapitalizma. Socijalna ekologija: časopis za ekološku misao i sociologijska istraživanja okoline 25(1-2): 191-208,

https://doi.org/10.17234/SocEkol.25.1.6

Morton, Timothy (2016). Dark Ecology. For a Logic of Future Coexistence.Columbia University Press

Painter, James i dr. (2017). Something Old, Something New: Digital Media and the Coverage of Climate Change. Reuters Institute for the Study of Journalism, Department of Politics and International Relations, University of Oxford

Reisigl, Martin i Ruth Wodak (2009). The discourse-historical approach. Wodak, Ruth i Michael Meyer (2009). Methods of Critical Discourse Analysis, 2nd edition. London: Sage Publications, 87-121

Sedlaczek, Andrea Sabine (2017). The field-specific representation of climate change in factual television: a multimodal critical discourse analysis. Critical Discourse Studies 14(5): 480-496, https://doi.org/10.1080/17405904.2017.1352003

Stibbe, Arran (2015). Ecolinguistics. Language, Ecology and the Stories We Live By. London and New York: Routledge

van Dijk, Teun. A. (2009). Society and discourse: how social contexts influence text and talk. Cambridge and New York: Cambridge University Press 
van Leeuwen, Theo (2003). The representation of social actors. Caldas-Coulthard, Carmen Rosa i Malcolm Coulthard (ur.) Texts and Practices. Readings in Critical Discourse Analysis. London: Routledge, 32-70

Wake, David B. i Vance T. Vredenburg (2008). Are we in the midst of the sixth mass extinction? A view from the world of amphibians. Proceedings of the National Academy of Sciences of the United States of America 105 (Supplement 1): 11466-11473, https://doi.org/10.1073/pnas.0801921105

Wagler, Ron (2013). Incorporating the current sixth great mass extinction theme into evolution education, science education, and environmental education research and standards. Evolution: Education and Outreach 6: 9, https://doi.org/10.1186/1936-6434-6-9

Wodak, Ruth i Michael Meyer (ur.) (2001). Methods of Critical Discourse Analysis. London: Sage Publications

Wodak, Ruth (2001). The discourse-historical approach. Wodak, Ruth i Michael Meyer (ur.) Methods of Critical Discourse Analysis. London: Sage Publications, 63-94

\section{Discursive construction of climate change in anglophone and Croatian online news media}

The paper presents findings of an exploratory research into the ways of discursively constructing the role of humans in climate change. Relying on the broad framework of ecolinguistics and critical discourse analysis, the authors conducted a comparative qualitative analysis of a corpus of texts published in Croatian and anglophone media in a limited, randomly chosen period. The aim of the research was to establish what "stories" (Stibbe 2015) related to this important social problem are given prominence in the analyzed corpus of Croatian and anglophone media texts, what points of common knowledge, i.e.«topoi« (Wodak 2001) are activated in the interpretation of these stories and what strategies of constructing "social actors" are used in the two corpora. The contrastive qualitative analysis makes it possible to gain insight into the differences in the focus of reporting, prominence given to particular (sub)topics in particular communities and rhetorical strategies used in shaping the discourse on climate change.

Ključne riječi: klimatske promjene, analiza diskursa, diskursne prakse, toposi, društveni akteri, hrvatski jezik, engleski jezik, ekolingvistika

Key words: climate change, discourse analysis, discourse practices, topoi, social actors, Croatian language, English language, ecolinguistics 